\title{
Repercussion effects of consumption by domestic tourists in Tokyo and Kyoto estimated using a regional waste input-output approach
}

\author{
Makiko Tsukui ${ }^{*} \mathbb{0}$, Takumi Ichikawa ${ }^{2}$ and Masaru Kagatsume ${ }^{3}$
}

*Correspondence:

makiko@tiu.ac.jp

${ }^{1}$ School of Business and Commerce, Tokyo

International University,

1-13-1 Matoba-Kita,

Kawagoe-shi, Saitama

350-1197, Japan

Full list of author information

is available at the end of the article

\begin{abstract}
As the economic importance of tourism increases, it is important to consider the effects that tourism has on the environment in the affected regions of the country. In our study, we selected two popular tourist destinations in Japan, Tokyo and Kyoto, for our case studies on the repercussion effects induced by the economic and environmental activities of visitors. As waste generation and landfilling are two of the most important environmental loads in Japan, a regional waste input-output approach was considered to be an effective method for evaluating these issues. The estimated direct effects of visitors' consumption activities in Tokyo and Kyoto amounted to approximately 434 billion yen and 209 billion yen, respectively. The tendencies of visitor consumption in both prefectures were similar, as were the repercussion effects on the production value, which accounted for approximately 434 billion yen and approximately 260 billion yen in Tokyo and Kyoto, respectively. Value added amounted to 276 billion yen in Tokyo and approximately 108 billion yen in Kyoto. Waste generation induced by tourists in Kyoto accounted for approximately 22,690 t, which was similar to that induced in Tokyo at 20,655 t. Regarding the repercussion effect of the area of landfill consumption, Kyoto tourists consumed $1479 \mathrm{~m}^{2}$ of landfill in contrast to $7369 \mathrm{~m}^{2}$ in Tokyo. The results of our study reveal the importance of considering the regional characteristics of the target region when conducting environmentally sound campaigns directed at stimulating tourism.
\end{abstract}

Keywords: Regional waste input-output approach, Tourism in Tokyo, Tourism in Kyoto

\section{Background}

The importance of tourism around the world is increasing. In 2014, direct, indirect, and induced economic effects of tourism amounted to 9\% of global GDP (United Nations World Tourism Organization (UNWTO), Tourism Highlights 2015). Moreover, the contribution of newly developing countries in the tourism market to this figure increased from 30 to $45 \%$ over the last 25 years, which means that tourism has been effective in improving economic well-being in these countries (UNWTO 2015). Hardy et al. (2002) reported that the three key factors in the development of sustainable tourism are environment vision, economic development, and community involvement. More recent

(c) The Author(s) 2017. This article is distributed under the terms of the Creative Commons Attribution 4.0 International License (http://creativecommons.org/licenses/by/4.0/), which permits unrestricted use, distribution, and reproduction in any medium, provided you give appropriate credit to the original author(s) and the source, provide a link to the Creative Commons license, and indicate if changes were made. 
studies have begun to examine the environmental loads induced by tourism (Ko 2005; Kytzia et al. 2011; Cernat and Gourdon 2012), although most early tourism studies evaluated only the economic benefits associated with tourism (Archer and Fletcher 1996; Fletcher 1989; Dwyer et al. 2000, 2004; Cai et al. 2006).

Investigating the economic and environmental effects of tourism is important, particularly in certain regions, because the priority associated with reducing environmental loads differs between regions. Economic repercussion effects are not usually limited to the target tourist site but also bring about economic benefits to other areas. However, an increase in tourism is also accompanied by an increase in waste, which is inevitably treated within the target tourist site (Lenzen 2008). Most Japanese tourist sites need to treat increased waste due to tourism because each municipality in Japan must basically treat general waste within the municipality. Moreover, it is extremely difficult to find new landfill sites in Japanese metropolitan cities, and one of the top priorities in these cities is to reduce landfill waste (Nakamura and Kondo 2002b; Sasao 2004; Tsukui et al. 2015). As such, waste generation and landfilling induced by tourists are crucial issues for sustainable tourism.

In a tourism study that considered the environment, Cernat and Gourdon (2012) developed the sustainable tourism-benchmarking tool (STBT), which they used to assess the sustainability of tourism using quantitative indicators initially proposed by Ko (2005) and Fernandez and Rivero (2009). Cernat and Gourdon (2012) conducted an input-output analysis to clarify economic linkages and leakages, which they used to investigate a variety of indicators, such as natural and cultural assets, economic activities, infrastructure, and environmental loads, including GHG emissions. Sun (2014) evaluated GHG emissions in Taiwan using the production and consumption accounting principles applied to the tourism satellite account (TSA) and environmentally extended inputoutput (EEIO) models. However, these authors did not quantitatively clarify the repercussion effects associated with waste generation or landfilling due to tourism. Other regional-level tourist studies have also examined the effect of tourism on waste generation. Johnson and Moore (1993) evaluated the impact of residents' and visitors' whitewater recreation activities on the Klamath River in Oregon, USA. Frechtling and Horvath (1999) estimated the direct, indirect, and induced impacts of tourism consumption on production and value added around Washington DC using the Regional Input-Output Modeling System (RIMSII). Specifically, they estimated the multiplier effects associated with tourist expenditure on the local regional economy. However, neither of these studies investigated the environmental loads induced by tourism.

Our study examines the impact of tourist consumption on tourist attractions in urban areas within the context of waste treatment using a regional waste input-output (WIO) approach. As mentioned previously, the scarcity of landfill sites in large cities is one of the most serious environmental problems affecting these areas. We therefore selected two popular metropolitan tourist destinations in Japan, Tokyo and Kyoto, as target regions for our case studies. We considered the effects of domestic tourism in these target regions, focusing on tourists from other parts of Japan. In the case of Tokyo, we used the interregional WIO (IR-WIO) table for Tokyo compiled in 2000 by Tsukui et al. (2015) to analyze the economic and environmental effects of domestic tourists from other regions. We clarified the tourism consumption in Kyoto and Tokyo as 
direct effects and estimated the resulting indirect effects in both regions. In our study, we define the combined direct and indirect effects as the repercussion effects. The WIO analysis (WIOA) developed by Nakamura and Kondo (2002a) is one of the most effective approaches for evaluating the interdependence between the flow of goods and waste. Case studies employing the WIOA have been conducted in a variety of countries and regions, including Japan (Nakamura and Kondo 2009), Australia (Reynolds et al. 2014; Fry et al. 2015), Taiwan (Liao et al. 2015), France (Beylot et al. 2016), and the UK (Salemdeeb et al. 2016). However, none of these studies evaluated the repercussion effects of tourism. For the Kyoto case study, we used the regional WIO table for Kyoto compiled in 2000 by Ichikawa et al. (2011). We then compared estimates of the direct and indirect effects of domestic tourism in these two regions on production value, value added, waste generation, waste transportation, landfilling, and GHG emissions.

The remainder of the present paper is structured as follows. Section 2 describes the regional WIO models used in the analysis. Section 3 presents the expenditure results estimated using a non-survey method for domestic tourists in Tokyo and Kyoto. Section 4 presents a comparison between the two regions with estimates of the repercussion effects for each region. Finally, conclusions and issues for future consideration are presented in Sect. 5.

\section{IR-WIO analysis model and tables}

In our study, we compared the repercussion effects for Tokyo and Kyoto in terms of domestic tourist expenditure using an IR-WIO approach. As mentioned in Sect. 1, the advantage of using an IR-WIO analysis to analyze the repercussion effects of consumption in a specific region is that economic and environmental effects, such as waste generation, transportation, and landfilling, can be considered simultaneously.

In our study, we applied the same two-region IR-WIO model that we applied in Tsukui et al. (2015). Briefly, the model is based on Kagawa and Kondo (2007) and Kagawa et al. (2007), which is an expansion of the conventional regional IO model of Isard (1951) and the WIO model of Nakamura and Kondo (2002a). A detailed description of this model has been provided in Tsukui et al. (2015). We estimated the repercussion effects of visitors' consumption on industrial sectors, waste generation, waste treatment sectors, and the environmental loads of each sector in Tokyo and Kyoto, respectively. Environmental loads, such as GHG emissions, can be estimated by multiplying generation coefficient matrices.

For the case study of Tokyo, we used an IR-WIO table for Tokyo for the year 2000, which we compiled in a previous study (Tsukui and Nakamura 2009; Tsukui et al. 2010, 2011a, b, c, 2015) and which was based on "The Interregional Input-Output Table in the Year 2000 in Tokyo" published by Tokyo Metropolitan General Affairs (TMGA 2007). In the Kyoto case study, we used a regional WIO table for the year 2000 in Kyoto (KWIOT2000), which was compiled by Ichikawa et al. (2011). To compile this table, Ichikawa et al. used the "Year 2000 Kyoto Prefecture Input-Output Table," published by Kyoto Prefecture (2004). We also referred to the industrial waste data published by the Ministry of the Environment Secretariat, Waste/Recycling Measures Department (2002) and NEDO (2005) for the estimation of waste generation from industrial sectors in both Tokyo and Kyoto. In order to apply the IR-WIO model described in Tsukui et al. (2015) 
to our study, we extended the KWIOT2000 to produce a two-region IR-WIO table (KIRWIOT2000) using Nakamura (2010). In the WIOTs for both Tokyo and Kyoto, estimating the activities of waste treatment sectors was based on Matsuto (2005). Estimates of the GHG emissions for each sector were based on the Embodied Energy and Emission Intensity Data for Japan Using Input-Output Tables (3EID) database (Nansai et al. 2008).

Since we had already developed a multi-regional WIO table for 47 prefectures of Japan (47WIOT) (Tsukui et al. 2014), we herein compare the advantages of each table before adopting a two-region IO framework in the case study. Using the 47WIOT, we can confirm the consistency of the data sets for investigating both Tokyo and Kyoto. However, the 47WIOT has only 46 industrial sectors and the two important sectors for investigating tourism, "Hotels and other lodging places" and "Eating and drinking places," are treated as belonging to the same sector, "Other personal services." Upon careful consideration of the advantages and disadvantages of the 47WIOT and WIO tables for Tokyo and Kyoto, we decided to adopt the WIO tables for use in our study.

\section{Domestic tourism consumption in Tokyo and Kyoto Prefectures}

Before presenting the results for the repercussion effects associated with tourist consumption in Tokyo and Kyoto, in this section, we clarify the differences in tourist expenditure between Tokyo and Kyoto.

We defined "tourists" as visitors from regions in Japan outside the target region who stayed overnight. While the primary objective of overnight visitors is tourism and shopping, the main purpose of day visitors (i.e., shopping or tourism) is more difficult to clarify.

For the analysis of Tokyo, we used the tourist expenditure data specified in the interregional input-output table (IR-IOT) for Tokyo 2000 (TMGA 2007), which we used to estimate the goods and services sector of the IR-WIO table for Tokyo in 2000 (Tsukui et al. 2015).

However, in the case of Kyoto, there was no category in the regional IO table for Kyoto 2000 showing consumption by visitors from other regions staying overnight, which was the basis for the WIO table for Kyoto compiled in our study, even in the most detailed version of the table, which included 104 sectors. We considered that the expenditure of visitors was incorporated into the "Household consumption expenditure" of the final consumption sector in the regional IOT of Kyoto. Thus, tourist consumption in Kyoto by residents of other regions was estimated by non-survey-based methods, as described in Sect. 3.2.

\subsection{Consumption by overnight stays by domestic tourists in Tokyo}

As mentioned in Sect. 3, estimates of the consumption by tourists staying overnight in Tokyo were used in the IR-IOT for Tokyo in 2000 (TMGA 2007). In the final demand sectors of the IR-IOT for Tokyo, "P9121-21 Expenditure by residents of other prefectures (commuting)," "P9121-22 Expenditure by residents of other prefectures (daytrip shopping excursions)," and "P9121-23 Expenditure by residents of other prefectures (overnight-stay shopping excursions)" were taken to correspond to the visitors' expenditure. We used "P9121-23" to indicate the expenditure of tourists from outside the target prefecture. Table 1 shows the expenditure by the visitors (i.e., "P9121-23") on individual 
Table 1 Consumption amounts induced by domestic tourists in Tokyo (TMGA 2007) (unit: million yen)

\begin{tabular}{|c|c|c|c|c|c|}
\hline Code & $\begin{array}{l}\text { Sector Classification } \\
\text { for IR-WIO table } \\
\text { for Tokyo in } 2000\end{array}$ & $\begin{array}{l}\text { Overnight-stay } \\
\text { tourist consumption } \\
\text { by residents of other } \\
\text { regions }\end{array}$ & Code & $\begin{array}{l}\text { Sector Classifica- } \\
\text { tion for IR-WIO table } \\
\text { for Tokyo in } 2000\end{array}$ & $\begin{array}{l}\text { Overnight-stay } \\
\text { tourist consumption } \\
\text { by residents of other } \\
\text { regions }\end{array}$ \\
\hline 1 & Crop cultivation & 124 & 73 & $\begin{array}{l}\text { Electronic comput- } \\
\text { ing equipment and } \\
\text { accessory equipment }\end{array}$ & 223 \\
\hline 3 & Agricultural services & 33 & 77 & Electronic components & 6 \\
\hline 5 & Fisheries & 3 & 79 & $\begin{array}{l}\text { Other electrical equip- } \\
\text { ments }\end{array}$ & 9 \\
\hline 12 & Foods & 1860 & 84 & Precision instruments & 606 \\
\hline 13 & Beverage & 606 & 85 & $\begin{array}{l}\text { Miscellaneous manu- } \\
\text { facturing products }\end{array}$ & 3197 \\
\hline 15 & Tobacco & 448 & 95 & Wholesale trade & 486 \\
\hline 16 & Textile products & 2 & 96 & Retail trade & 456 \\
\hline 17 & $\begin{array}{l}\text { Wearing apparel } \\
\text { and other textile } \\
\text { products }\end{array}$ & 3587 & 97 & $\begin{array}{l}\text { Financial and insurance } \\
\text { services }\end{array}$ & 1412 \\
\hline 18 & $\begin{array}{l}\text { Timber and wooden } \\
\text { products }\end{array}$ & 3 & 101 & Rail transport & 42,087 \\
\hline 19 & Furniture and fixtures & 18 & 102 & Railway transport & 22,298 \\
\hline 21 & Paper and paperboard & 1 & 104 & $\begin{array}{l}\text { Road transport (except } \\
\text { transport by private } \\
\text { cars) }\end{array}$ & 33 \\
\hline 23 & Paper products & 255 & 105 & Air transport & 7817 \\
\hline 24 & $\begin{array}{l}\text { Publishing and print- } \\
\text { ing }\end{array}$ & 2805 & 108 & $\begin{array}{l}\text { Services relating to } \\
\text { transport }\end{array}$ & 2161 \\
\hline 31 & Medicaments & 9 & 109 & Communication & 596 \\
\hline 32 & $\begin{array}{l}\text { Chemical final } \\
\text { products (excluding } \\
\text { medicaments) }\end{array}$ & 332 & 110 & Broadcasting & 591 \\
\hline 33 & $\begin{array}{l}\text { Petroleum refinery } \\
\text { products }\end{array}$ & 47 & 112 & Education & 732 \\
\hline 36 & Plastic products & 6 & 118 & Other public services & 1891 \\
\hline 37 & Rubber products & 35 & 120 & $\begin{array}{l}\text { Goods rental and leas- } \\
\text { ing services }\end{array}$ & 261 \\
\hline 38 & $\begin{array}{l}\text { Leather, fur skins, } \\
\text { and miscellaneous } \\
\text { leather products }\end{array}$ & 1020 & 121 & $\begin{array}{l}\text { Repair of motor } \\
\text { vehicles }\end{array}$ & 3406 \\
\hline 39 & $\begin{array}{l}\text { Glass and glass } \\
\text { products }\end{array}$ & 4 & 124 & $\begin{array}{l}\text { Amusement and rec- } \\
\text { reational services }\end{array}$ & 33,436 \\
\hline 43 & $\begin{array}{l}\text { Pottery, china, and } \\
\text { earthenware }\end{array}$ & 9 & 125 & $\begin{array}{l}\text { Eating and drinking } \\
\text { places }\end{array}$ & 79,124 \\
\hline 57 & $\begin{array}{l}\text { Other non-ferrous } \\
\text { metals }\end{array}$ & 65 & 126 & $\begin{array}{l}\text { Hotels and other lodg- } \\
\text { ing places }\end{array}$ & 204,251 \\
\hline 72 & $\begin{array}{l}\text { Household electronic } \\
\text { and electric appli- } \\
\text { ances }\end{array}$ & 442 & 127 & $\begin{array}{l}\text { Other personal } \\
\text { services }\end{array}$ & 17,241 \\
\hline
\end{tabular}

industrial products in Tokyo. In Sect. 4, the repercussion effects of visitors from regions other than Tokyo staying overnight are estimated based on the results of direct effects shown in Table 1. 


\subsection{Estimated consumption by overnight stays by domestic tourists to Kyoto Prefecture}

We estimated the consumption induced by overnight stays by domestic tourists visiting Kyoto Prefecture based on the Kyoto City survey. The center of tourism in Kyoto Prefecture is the city of Kyoto. In 2000, which is the reference year for our study, consumption by tourists in Kyoto City comprised 90\% of the tourist consumption in the entire prefecture (City of Kyoto 2011). Kyoto City published the "Kyoto City Annual Tourism Survey Report" based on a random-sample questionnaire survey (City of Kyoto 2011), which examined aspects such as the type of transportation facilities used, number of day/overnight tourists, point of departure, duration of stay, breakdown of tourist consumption amounts, and souvenir purchases. In our study, we assumed that the consumption activities of tourists to Kyoto Prefecture were equivalent to those for Kyoto City. In this way, we expanded our analysis to Kyoto Prefecture in its entirety (Table 2).

The method used to estimate the number of overnight stays by domestic tourists in Kyoto Prefecture (i.e., Kyoto City) was as follows. The "2001 Kyoto City Annual Tourism Survey Report" (Kyoto City 2002) was published by Kyoto City in 2002, which is very close to the base year of our study (i.e., 2000). The number of foreign visitors was deducted from the total of 9423 million tourists who stayed overnight in Kyoto. The number of domestic tourists visiting Kyoto Prefecture was estimated to be 7.9 million people, based on the point of departure information contained in the "2001 Kyoto City Annual Tourism Survey Report."

In the Kyoto City survey, tourist consumption was classified as "Travel expenses within the city," "Lodging expenses," "Souvenir expenses," "Dining expenses," or "Other expenses." With regard to "Travel expenses within the city", the Kyoto City survey revealed that the percentages of tourists using Japan Railways (JR), private rail, buses, and passenger vehicles were 33.3, 27.6, 9.0, and 30.1\%, respectively. The statistics for JR and private rail were used to estimate the demand for "78 Rail transport" in KIRWIOT2000, and the statistics for buses were used to estimate the demand for "79 Road transport." According to the Kyoto City survey, private automobiles, rental cars, and taxis/hired cars were also used, and these means of transportation were grouped under "Automobile." Since these categories were not specified in the Kyoto City survey, their proportions were estimated by referencing the "Travel and Tourism Consumption Trends Survey" [Ministry of Land, Infrastructure, Transport and Tourism (MLITT) 2004]. As a result, we hypothesized that "Automobile" could be subdivided as follows: private automobile, 95.6\%; rental car, 3.9\%; and taxis/hired cars, $0.6 \%$.

We also referred to the "Travel and Tourism Consumption Trends Survey" (MLITT 2004) to estimate the visitors' expenditure per person in Kyoto. We estimated "Travel expenses within the city" using the Kyoto City survey data by multiplying the number of users of each transportation mode by the unit purchase price provided by "Travel and Tourism Consumption Trends Survey" and then allotting the "Travel expenses within the city" to the corresponding industrial sectors in Table 2. "Lodging expenses" were taken as the demand for "101 Inns and other lodgings," and "Dining expenses" were taken as "100 Eating and drinking places." "Souvenir expenses" were estimated after referencing the standard classifications used in the national IO table compiled by the Ministry of Internal Affairs and Communications (MIC 2004), based on survey results concerning souvenir purchase conditions in Kyoto City and the research of Hamada (2009). "Other 
Table 2 Estimated consumption amounts induced by domestic tourists in Kyoto Prefecture

\begin{tabular}{|c|c|c|c|c|c|}
\hline $\begin{array}{l}\text { Kyoto City clas- } \\
\text { sification }\end{array}$ & Breakdown & Details & Code & $\begin{array}{l}\text { KIRWIOT2000 sec- } \\
\text { tor classification }\end{array}$ & $\begin{array}{l}\text { Consumption } \\
\text { amount }(10,000 \\
\text { yen) }\end{array}$ \\
\hline \multirow{9}{*}{$\begin{array}{l}\text { Travel expenses } \\
\text { within the city }\end{array}$} & $J R$ & & 78 & Rail transport & 730,724 \\
\hline & Private rail & & 78 & Rail transport & 607,101 \\
\hline & Bus & & 79 & Road transport & 146,112 \\
\hline & Taxi/hired car & & 79 & Road transport & 2518 \\
\hline & Private automobile & Gasoline cost & 31 & $\begin{array}{l}\text { Petroleum refinery } \\
\text { products }\end{array}$ & 710,952 \\
\hline & & $\begin{array}{l}\text { Parking/toll road } \\
\text { fee }\end{array}$ & 85 & $\begin{array}{l}\text { Services relating to } \\
\text { transport }\end{array}$ & 871,211 \\
\hline & Rent-a-car & $\begin{array}{l}\text { Rent-a-car } \\
\text { expenses }\end{array}$ & 96 & $\begin{array}{l}\text { Goods rental and } \\
\text { leasing services }\end{array}$ & 74,060 \\
\hline & & Gasoline cost & 31 & $\begin{array}{l}\text { Petroleum refinery } \\
\text { products }\end{array}$ & 28,684 \\
\hline & & $\begin{array}{l}\text { Parking/toll road } \\
\text { fee }\end{array}$ & 85 & $\begin{array}{l}\text { Services relating to } \\
\text { transport }\end{array}$ & 35,150 \\
\hline Lodging expenses & & & 101 & $\begin{array}{l}\text { Hotels and other } \\
\text { lodging places }\end{array}$ & $10,084,494$ \\
\hline \multirow[t]{15}{*}{ Souvenir expenses } & Confectioneries & & 10 & Foods & 257,137 \\
\hline & Pickled vegetables & & 10 & Foods & 95,159 \\
\hline & Dried bean curd & & 10 & Foods & 6426 \\
\hline & $\begin{array}{l}\text { Pickled sliced } \\
\text { radishes }\end{array}$ & & 10 & Foods & 6426 \\
\hline & $\begin{array}{l}\text { Salted chopped } \\
\text { pickled vegeta- } \\
\text { bles }\end{array}$ & & 10 & Foods & 5438 \\
\hline & Uji tea & & 12 & Japanese tea & 12,276 \\
\hline & $\begin{array}{l}\text { Other flavored } \\
\text { goods }\end{array}$ & & 10 & Foods & 32,626 \\
\hline & $\begin{array}{l}\text { Ornaments/arts } \\
\text { and crafts }\end{array}$ & & 38 & $\begin{array}{l}\text { Pottery, china, and } \\
\text { earthenware }\end{array}$ & 3536 \\
\hline & $\begin{array}{l}\text { Pottery and por- } \\
\text { celain }\end{array}$ & & 38 & $\begin{array}{l}\text { Pottery, china, and } \\
\text { earthenware }\end{array}$ & 17,680 \\
\hline & Picture postcards & & 22 & $\begin{array}{l}\text { Publishing and } \\
\text { printing }\end{array}$ & 1176 \\
\hline & Accessories & & 64 & $\begin{array}{l}\text { Miscellaneous } \\
\text { manufacturing } \\
\text { products }\end{array}$ & 9019 \\
\hline & $\begin{array}{l}\text { Apparel/furnish- } \\
\text { ings, etc. }\end{array}$ & & 19 & $\begin{array}{l}\text { Furniture and } \\
\text { fixtures }\end{array}$ & 72,753 \\
\hline & Purses/handbags & & 17 & $\begin{array}{l}\text { Wearing apparel } \\
\text { and other textile } \\
\text { products }\end{array}$ & 16,177 \\
\hline & Nishijin fabrics & & 17 & $\begin{array}{l}\text { Wearing apparel } \\
\text { and other textile } \\
\text { products }\end{array}$ & 6844 \\
\hline & Dyed fabrics, etc. & & 17 & $\begin{array}{l}\text { Wearing apparel } \\
\text { and other textile } \\
\text { products }\end{array}$ & 23,021 \\
\hline Dining expenses & & & 100 & $\begin{array}{l}\text { Eating and drinking } \\
\text { places }\end{array}$ & 5633,912 \\
\hline Other expenses & Shoes/bags & & 35 & $\begin{array}{l}\text { Leather, fur skins, } \\
\text { and miscel- } \\
\text { laneous leather } \\
\text { products }\end{array}$ & 232,316 \\
\hline
\end{tabular}


Table 2 continued

\begin{tabular}{|c|c|c|c|c|}
\hline $\begin{array}{l}\text { Kyoto City clas- } \\
\text { sification }\end{array}$ & Breakdown & Code & $\begin{array}{l}\text { KIRWIOT2000 sec- } \\
\text { tor classification }\end{array}$ & $\begin{array}{l}\text { Consumption } \\
\text { amount }(10,000 \\
\text { yen) }\end{array}$ \\
\hline & $\begin{array}{l}\text { Medicinal prod- } \\
\text { ucts/cosmetics/ } \\
\text { oral hygiene } \\
\text { products, etc. }\end{array}$ & 30 & $\begin{array}{l}\text { Final chemical } \\
\text { products }\end{array}$ & 58,079 \\
\hline & Film & 30 & $\begin{array}{l}\text { Final chemical } \\
\text { products }\end{array}$ & 58,079 \\
\hline & $\begin{array}{l}\text { Cameras/watches/ } \\
\text { glasses }\end{array}$ & 63 & $\begin{array}{l}\text { Precision instru- } \\
\text { ments }\end{array}$ & 58,079 \\
\hline & $\begin{array}{l}\text { Other manufac- } \\
\text { tured goods } \\
\text { (stationary/toys, } \\
\text { etc.) }\end{array}$ & 64 & $\begin{array}{l}\text { Miscellaneous } \\
\text { manufacturing } \\
\text { products }\end{array}$ & 290,395 \\
\hline & $\begin{array}{l}\text { Hot spring visits/ } \\
\text { hot spring facili- } \\
\text { ties/beauty salons }\end{array}$ & 99 & $\begin{array}{l}\text { Amusement and } \\
\text { recreational } \\
\text { services }\end{array}$ & 232,316 \\
\hline & $\begin{array}{l}\text { Theme parks/ } \\
\text { amusement } \\
\text { parks, etc. }\end{array}$ & 102 & $\begin{array}{l}\text { Other personal } \\
\text { services }\end{array}$ & 522,712 \\
\hline & $\begin{array}{l}\text { Art galleries/muse- } \\
\text { ums, etc. }\end{array}$ & 89 & Education & 290,395 \\
\hline & $\begin{array}{l}\text { Golf courses/tennis } \\
\text { courts, etc. }\end{array}$ & 99 & $\begin{array}{l}\text { Amusement and } \\
\text { recreational } \\
\text { services }\end{array}$ & 348,474 \\
\hline & Ski slopes & 99 & $\begin{array}{l}\text { Amusement and } \\
\text { recreational } \\
\text { services }\end{array}$ & 58,079 \\
\hline & $\begin{array}{l}\text { Watching sports/art } \\
\text { appreciation }\end{array}$ & 99 & $\begin{array}{l}\text { Amusement and } \\
\text { recreational } \\
\text { services }\end{array}$ & 116,158 \\
\hline & $\begin{array}{l}\text { Exhibitions/con- } \\
\text { ventions }\end{array}$ & 89 & Education & 58,079 \\
\hline & Tour guide costs & 102 & $\begin{array}{l}\text { Other personal } \\
\text { services }\end{array}$ & 58,079 \\
\hline & Massage & 102 & $\begin{array}{l}\text { Other personal } \\
\text { services }\end{array}$ & 116,158 \\
\hline & $\begin{array}{l}\text { Photography } \\
\text { expenses }\end{array}$ & 102 & $\begin{array}{l}\text { Other personal } \\
\text { services }\end{array}$ & 58,079 \\
\hline & $\begin{array}{l}\text { Postal services/ } \\
\text { telephone com- } \\
\text { munication costs }\end{array}$ & 86 & Communication & 116,158 \\
\hline & Delivery services & 79 & Road transport & 232,316 \\
\hline & Other & 102 & $\begin{array}{l}\text { Other personal } \\
\text { services }\end{array}$ & 871,186 \\
\hline
\end{tabular}

expenses" in the Kyoto City survey were estimated based on the breakdown of corresponding categories of tourist expenditures in the "Travel and Tourism Consumption Trends Survey" (MLITT 2004). Then, we allocated each category of MLITT (2004) to the corresponding IOT industrial sector. Estimates were expanded to Kyoto Prefecture using these results based on the aforementioned assumptions. Table 2 shows the results estimated for each industrial sector, and the purchaser price was converted into the producer price based on the national IO table of the MIC. The final estimation results are shown in Table 3. 
Table 3 Consumption by visitors in the Kyoto case study (KIRWIOT2000 sector classification)

\begin{tabular}{|c|c|c|}
\hline Code & KIRWIOT2000 sector classification & $\begin{array}{l}\text { Estimated value of consump- } \\
\text { tion by domestic tourists } \\
(10,000 \text { yen })\end{array}$ \\
\hline 10 & Foods & 220,331 \\
\hline 12 & Japanese tea & 6772 \\
\hline 17 & Clothing and other textile products & 19,004 \\
\hline 19 & Furniture and fixtures & 29,805 \\
\hline 22 & Publishing and printing & 525 \\
\hline 30 & Final chemical products & 55,659 \\
\hline 31 & Petroleum refinery products & 449,920 \\
\hline 35 & Leather, furs, and miscellaneous leather products & 113,762 \\
\hline 38 & Pottery, china, and earthenware & 9602 \\
\hline 63 & Precision instruments & 30,040 \\
\hline 64 & Miscellaneous manufacturing products & 130,599 \\
\hline 74 & Commerce & 519,807 \\
\hline 78 & Rail transport & $1,213,502$ \\
\hline 79 & Road transport & 544,009 \\
\hline 81 & Water transport & 1580 \\
\hline 82 & Air transport & 323 \\
\hline 84 & Storage facility service & 2171 \\
\hline 85 & Services relating to transport & 815,572 \\
\hline 86 & Communication & 104,523 \\
\hline 89 & Education & 313,568 \\
\hline 96 & Goods rental and leasing services & 66,642 \\
\hline 99 & Amusement and recreational services & 679,398 \\
\hline 100 & Eating and drinking places & $5,069,574$ \\
\hline 101 & Hotels and other lodging places & $9,074,349$ \\
\hline 102 & Other personal services & $1,463,319$ \\
\hline
\end{tabular}

\subsection{Comparison of the direct effects of domestic tourism consumption in Tokyo and Kyoto Prefectures}

What is the difference in expenditure when visiting Tokyo or Kyoto? Comparing these two regions reveals that consumption in Tokyo amounted to 434.0 billion yen for approximately 32 million visitors in 2004, while that in Kyoto was 209.3 billion yen for approximately 11 million visitors in 2001 (City of Kyoto Industry and Tourism Bureau 2002; Tokyo Convention and Visitors Bureau 2004). However, considering that the household consumption in Tokyo is close to seven times that in Kyoto Prefecture, overnight stays by domestic tourists were extremely important for Kyoto Prefecture.

How do the consumption trends for overnight stays by domestic tourists differ between Tokyo and Kyoto? As shown in Fig. 1, tourist expenses are generally similar in both prefectures. "Hotels and other lodging places" was the largest expense, which accounted for approximately 45\%, and "Eating and drinking places" accounted for approximately $20 \%$ in both regions.

However, of the differences observed, there was a slight increase in demand for "Air transport" in Tokyo. This was likely because tourism is one of the main industries on 


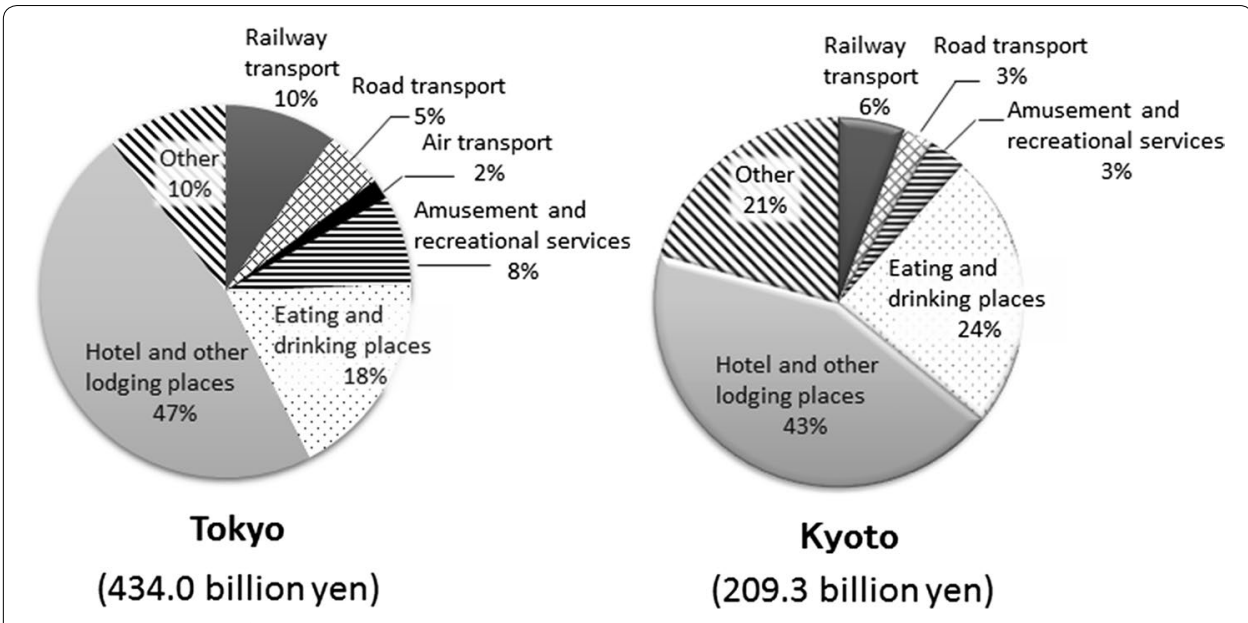

Fig. 1 Proportion of overnight stays by domestic tourists in Tokyo and Kyoto

Izu and Ogasawara islands, ${ }^{1}$ both of which fall under the jurisdiction of Tokyo. In addition, "Rail transport" in Tokyo is slightly more important than "Road transport." "Services relating to transport" and "Petroleum refinery products" in Kyoto, which are included in the category of "Other" in Fig. 1, accounted for approximately 3.9 and $2.1 \%$, respectively, which are much larger than the corresponding figures for Tokyo.

The expense for "Eating and drinking places" sector is proportionately larger in Kyoto Prefecture, and the "Recreational services" is larger in Tokyo. The Kyoto City survey of local attractions includes numerous scenic and historical sites, such as Kiyomizu-dera, Arashiyama, Kinkakuji, and Ginkakuji, ${ }^{2}$ and almost no facilities are listed that correspond to "Recreational services." Differences in items, such as tourism areas, are reflected in the breakdown of tourism consumption. The expenses in Kyoto for "Other personal services" (7.0\%), "Commerce" (2.5\%), and "Foods" (1.1\%) are also larger than in Tokyo.

Although the direct consumption trends were basically similar, the repercussion effects differed according to the industrial structures within Tokyo and Kyoto Prefectures. In addition, in our study, the waste generated by domestic tourists is categorized as business waste by the industrial sector, such as food waste from restaurants and hotels. Consequently, differences in the economic structures of Tokyo and Kyoto Prefectures are considered to be closely related to the impact of waste generation.

\section{Comparison of the repercussion effects induced by domestic tourism consumption in Tokyo and Kyoto Prefectures}

In this section, we compare the repercussion effects in Tokyo and Kyoto of the domestic tourist expenditures described in Sect. 3. As shown above, consumption by domestic tourists staying overnight in Kyoto Prefecture is less than half that for Tokyo. We

\footnotetext{
${ }^{1}$ Izu and Ogasawara islands are located approximately 120-1000 km south of Tokyo bay and are famous for their natural beauty. The Ogasawara islands are recognized as a natural heritage site by UNESCO. The primary means of access to these islands are by ship and by air.

2 Kiyomizu-dera, Kinkakuji, and Ginkakuji are the most popular Buddhist temples in Kyoto and are recognized as world heritage sites by UNESCO. Arashiyama is located on the east side of Kyoto City and is famous for its superb views, especially during cherry blossom season and autumn.
} 
considered the disparity in magnitude of the economic activities of the two prefectures when we investigated and compared the repercussion effects induced by tourist consumption in Tokyo and Kyoto.

First, the impacts were compared from an economic perspective. The repercussion effects on the production value attributed to consumption by domestic tourists were approximately 434 billion yen in Tokyo and 260 billion yen in Kyoto. Considering that the direct effects of tourism in Tokyo were twice as large as those in Kyoto, the repercussion effects on the production value in both regions were relatively similar. The valueadded repercussion effects amounted to approximately 276 billion yen in Tokyo and approximately 108 billion yen in Kyoto.

The trends in repercussion effects on production and value-added effects were similar between Tokyo and Kyoto. The repercussion effects on civil services and the service industry were $62.7 \%$ in Tokyo and $68.0 \%$ in Kyoto, on traffic, telecom, and broadcasting were $17.2 \%$ in Tokyo and $13.0 \%$ in Kyoto, on commerce were $10.8 \%$ in Tokyo and $8.0 \%$ in Kyoto, and on secondary manufacturing industries were $6.3 \%$ in Tokyo and $8.5 \%$ in Kyoto. However, the impacts on certain industries differed between Tokyo and Kyoto (Table 4). The repercussion effects of the production value on "Hotels and other lodging places," "Eating and drinking places," and "Amusement and recreational services" accounted for more than $50 \%$ in both regions. The repercussion effect on "Hotels and other lodging places" was larger in Kyoto than in Tokyo. Moreover, the repercussion effect on "Amusement and recreational services" in Kyoto was half that in Tokyo. As mentioned in Sect. 3.2, regarding the direct effects of tourists' consumption of goods and services, the repercussion effect on "Amusement and recreational services" in Kyoto is smaller than that in Tokyo because, unlike in Tokyo, most of the tourists visiting Kyoto go to historical attractions, such as shrines and temples. The repercussion effect on "Financial and insurance services" was also larger in Tokyo than in Kyoto. Since most insurance companies have their headquarters in Tokyo, the repercussion effects of travel insurance are larger in Tokyo than in Kyoto. In Kyoto, the repercussion effect

Table 4 Repercussion effects on production value in Tokyo and Kyoto (million yen)

\begin{tabular}{lrrrr}
\hline Industry & Tokyo & & Kyoto & \\
\hline Foods & 8575 & $2 \%$ & 5914 & $2 \%$ \\
Petroleum refinery products & 99 & $0 \%$ & 4634 & $2 \%$ \\
Commerce & 19,597 & $4 \%$ & 9993 & $4 \%$ \\
Financial and insurance services & 26,948 & $5 \%$ & 7996 & $3 \%$ \\
Railway transport & 42,309 & $8 \%$ & 12,447 & $5 \%$ \\
Road transport & 23,085 & $4 \%$ & 6432 & $2 \%$ \\
Services relating to transport & 6701 & $1 \%$ & 9005 & $3 \%$ \\
Advertising, survey, and information services & 10,441 & $2 \%$ & 1523 & $1 \%$ \\
Other business services & 9153 & $2 \%$ & 2784 & $1 \%$ \\
Amusement and recreational services & 38,676 & $7 \%$ & 7255 & $3 \%$ \\
Eating and drinking places & 76,641 & $15 \%$ & 50,696 & $19 \%$ \\
Hotels and other lodging places & 152,127 & $29 \%$ & 90,743 & $35 \%$ \\
Other personal services & 20,876 & $4 \%$ & 15,841 & $6 \%$ \\
Other & 23,209 & $4 \%$ & 11,641 & $4 \%$ \\
\hline
\end{tabular}


on "Petroleum refinery products" accounted for 4634 million yen, which is considerably larger than that in Tokyo. This disparity in repercussion effects associated with petroleum products exists because there is no petroleum industry in Tokyo. Indeed, all petroleum products are imported to Tokyo from other parts of Japan. A production value of 8032 million yen for petroleum products was induced in areas outside Tokyo. As shown in Fig. 2, the difference in the repercussion effects on the production value is caused by differences in the economic structures of Tokyo and Kyoto. Whereas the main industry in Tokyo is the service industry, in Kyoto, the main industries are manufacturing industries, including the automotive industry, the food industry, industries producing semiconductor devices and integrated circuits, and the publishing and printing industries. The difference in the economic structures of Tokyo and Kyoto also affects the amounts and types of waste generated.

Table 5 shows the repercussion effects of waste generation (considering recycling) in Tokyo and Kyoto. Although the direct and indirect effects on the production value in Kyoto are half that in Tokyo, the induced waste generation for Kyoto is as same as that for Tokyo. Business waste is generated by the service industries, such as "Hotels and other lodging places" and "Eating and drinking places," and waste generation by these industries is larger in Kyoto than in Tokyo. As shown in Fig. 2, the difference in industrial waste generation is mainly attributable to differences in the economic structure of Tokyo and Kyoto. The main industries in Kyoto are manufacturing industries, which have higher waste generation coefficients than the tertiary industries that dominate Tokyo. Kyoto is also famous for its livestock industry, and "Livestock excreta and livestock corpses" accounts for a total of 3345 tonnes of industrial waste, which is considerably larger than that generated in Tokyo.

As indicated by the results shown in Table 5, the waste generation induced in Kyoto by "Waste oil," "Waste acid," "Waste alkali," and "Waste plastics" accounted for -1616 , 22,15 , and $-2778 \mathrm{t}$, respectively (total: $-4356 \mathrm{t}$ ). The reason why some repercussion effects are negative is that the amount of waste that is recycled is larger than that generated in these waste categories. For example, in "Road transport" consumption by tourists induced production activity in the petroleum industry that recycled $1655 \mathrm{t}$ of waste

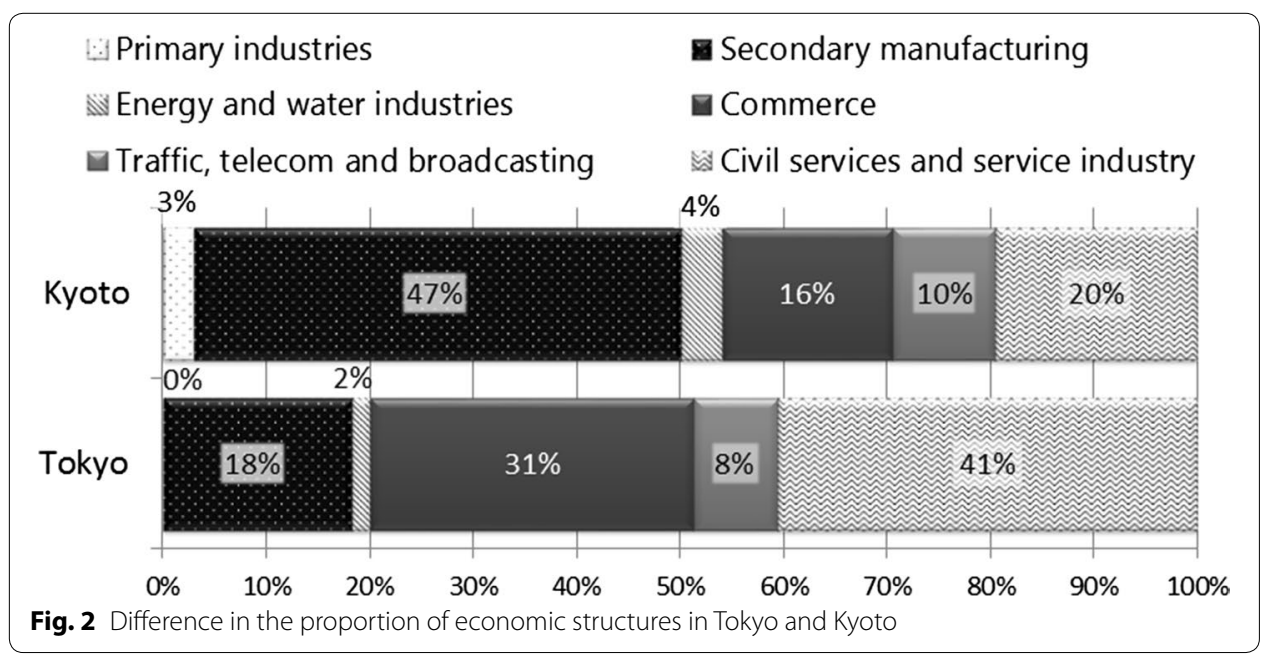


Table 5 Repercussion effects on waste generation considering recycling (t)

\begin{tabular}{lrr}
\hline Waste category & Tokyo & Kyoto \\
\hline Business waste & & 6960 \\
Food waste & 6167 & 5955 \\
Waste paper and waste textiles & 4955 & 1886 \\
Waste plastics & 2058 & 386 \\
Scrap metal & 1359 & 1037 \\
Waste bottles and waste ceramics & 470 & 230 \\
Other & 1078 & \\
Industrial waste & & 1435 \\
Sludge & 2539 & -4356 \\
Waste oil, waste acid, waste alkali, and waste plastics & 289 & 79 \\
Waste paper, wood, fibers, animal and vegetable residue, and rubber & 21 & 321 \\
Scrap metal & 29 & 1782 \\
Construction waste, waste glass, waste ceramics, and slag & 908 & 3345 \\
Livestock excreta and livestock corpses & 517 & 2680 \\
Cinder, dust, and molten slag & 10 & 0 \\
Shredder dust & 0 & 22,690 \\
Total & 20,655 & \\
\hline
\end{tabular}

oil and $3140 \mathrm{t}$ of waste plastics. In KIRWIOT2000, "Waste oil" and "Waste plastics" are generated by other chemical industries, but these industries are not stimulated by tourist consumption. The relative amount of "Cinder, dust, and molten slag" from Kyoto, which accounted for $2680 \mathrm{t}$, is also much larger than that from Tokyo. In investigating which industrial sectors generate "Cinders, dust, molten slag" waste, the repercussion effect of "Dust" from the "Electricity" industry in Kyoto is 2286 t. Kyoto Prefecture has a thermal power plant at Maizuru, which uses primarily coal and crude oil as fuel (KEPCO 2011). In contrast, in 2000, most thermal power plants in Tokyo were off-line or used natural gas, which produces only small amounts of "Dust." Therefore, the quantity of "Dust" produced in Tokyo and Kyoto appears to differ markedly between the two prefectures. Since there has been a change in the usage of power plants and fuels since the Great East Japan Earthquake in March 2011, the results may differ if the analysis is performed using more recent data.

The large amounts of waste generated led to a large amount of landfill waste. Regarding the repercussion effect of landfill consumption area, Kyoto consumed $1479 \mathrm{~m}^{2}$ of landfill compared to $7369 \mathrm{~m}^{2}$ for Tokyo. This appears to contradict the results indicating that waste generation, which is induced by visitors' consumption in Kyoto, was the same as that in Tokyo. The reason for the observed disparity in landfill consumption area is because the waste categories associated with waste generation in Kyoto, which was larger than that in Tokyo, were mainly treated in incineration facilities. Since incineration effectively reduces the amount of residue that needs to be landfilled, Kyoto consumed less landfill than Tokyo. For example, in Kyoto, 15\% of the induced waste generation belonged to the "Livestock excreta, Livestock corpses" category, which was incinerated. In contrast, in Tokyo, the induced waste generation of "Scrap metal," considering recycling, accounted for approximately 1359 tonnes, which is 3.5 times larger than that in Kyoto. Scrap metal is difficult to reduce in size and is directly landfilled (Fig. 3). 


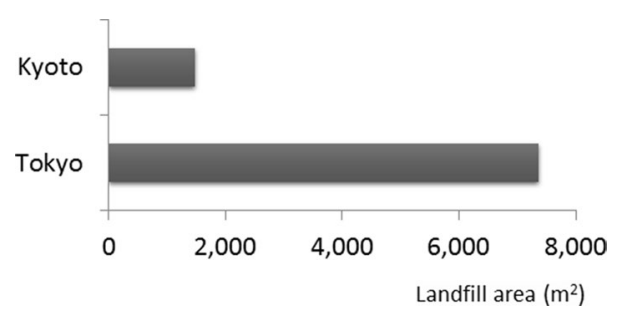

Fig. 3 Repercussion effects of landfill consumption area in Tokyo and Kyoto

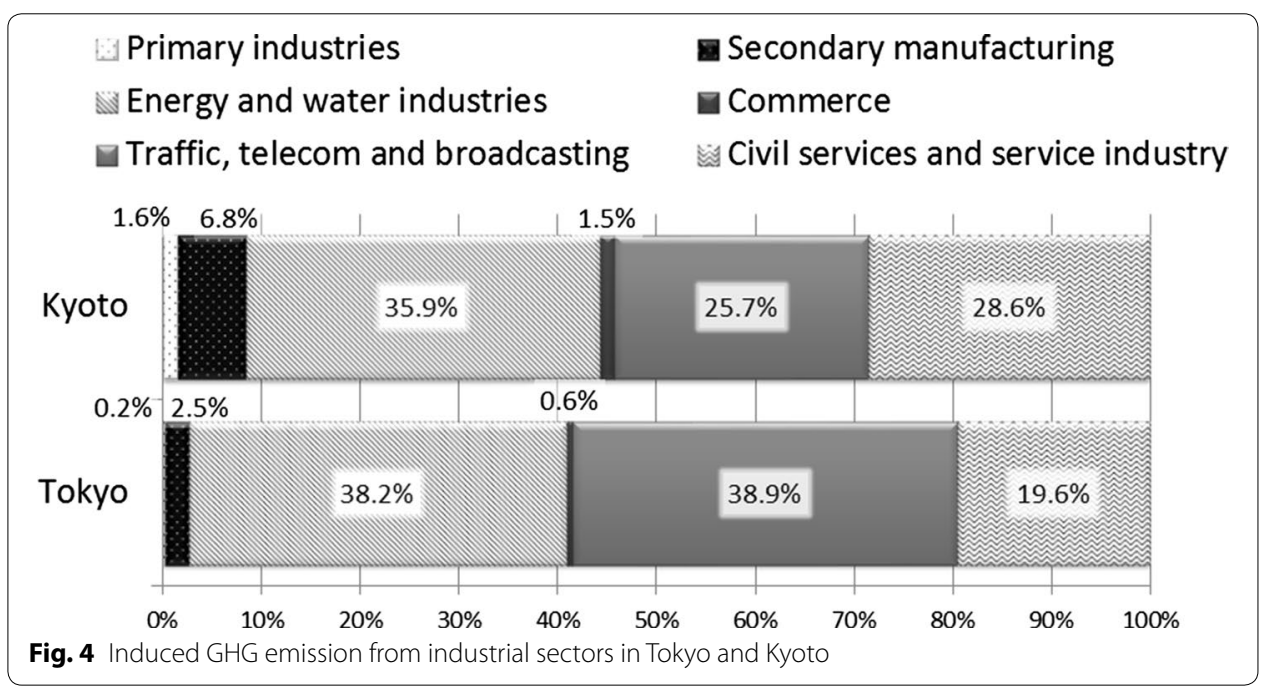

For the repercussion effects of GHG emissions, a noticeable difference was observed between Tokyo and Kyoto. The repercussion effect of GHG emissions in Tokyo was $269,945 \mathrm{t}-\mathrm{CO}_{2}$ (eq.), whereas that in Kyoto was $141,103 \mathrm{t}-\mathrm{CO}_{2}$ (eq.). However, as shown in Fig. 4, the proportion of GHG emissions by the industries of Tokyo and Kyoto was quite different. As stated in Sect. 3.2, the direct effect of transportation and trafficrelated activities is high for Tokyo, and "Road transport" and "Air transport," which have high GHG emission coefficients, also have high relative importance in Tokyo.

\section{Conclusions}

Our study analyzed the direct and indirect effects of consumption by domestic tourists using a regional WIO analysis, which enabled us to investigate the economic and environmental impacts of final consumption induced by tourism. As indicators of environmental loads, we focused on waste generation, landfilling, and GHG emissions. We conducted case studies in Tokyo and Kyoto and compared the direct and indirect effects induced by visitors from other parts of Japan.

The findings revealed that the economic impacts of tourism in Tokyo and Kyoto were generally similar, but the environmental impacts of domestic tourism were quite different. Although the magnitude of the direct and indirect effects was much larger in Tokyo, tourism was more important in Kyoto than in Tokyo. Similarly, although the amount of 
waste induced in both regions was similar, the amount of landfill generated in Tokyo was approximately five times larger than that in Kyoto. The GHG emissions in both regions were approximately proportional to the direct effects of domestic visitors' consumption, but the industries that emitted GHGs were quite different in each area, reflecting differences in the economic structures of Tokyo and Kyoto. The results of our study also demonstrated the need for considering the regional characteristics of the target region when promoting tourism in a way that is environmentally sound.

Future research should examine the importance of the interregional relationships between different areas of a country. When a site attracts tourists, it sometimes induces large environmental loads in other parts of the country. For example, economic activities that are stimulated by tourism, such as shopping, eating in restaurants, and lodging, which generate relatively small environmental loads, tend to stimulate production activities in industries such as agriculture, the food industry, and manufacturing, which have larger environmental loads. Hasegawa et al. (2015) constructed a multi-regional IO table for 47 prefectures in Japan (47IOT) in order to evaluate the carbon footprint of each region. Expanding the 47IOT to include environmental loads other than GHG emissions would allow the direct and indirect effects of tourism to be clarified within the context of the interregional economic and environmental relationships between regions. It is also important to consider the effect of the Great East Japan Earthquake in 2011, particularly insofar as the shift in power generation methods in Japan is concerned. The model and data obtained in our study provide a powerful tool for investigating the economic and environmental impacts of tourism.

\begin{abstract}
Abbreviations
EEIO: environmentally extended input-output; IR-WIO: interregional WIO; KWIOT2000: regional WIO table for the year 2000 in Kyoto; KIRWIOT2000: two-region interregional WIO table; MLITT: Ministry of Land, Infrastructure, Transport and Tourism; TMGA: Tokyo Metropolitan General Affairs; WIO: waste input-output; WIOA: WIO analysis; 3EID: Embodied Energy and Emission Intensity Data for Japan Using Input-Output Tables; $47 \mathrm{IOT}$ : multi-regional IO table for 47 prefectures in Japan; 47WIOT: multi-regional WIO table for 47 prefectures in Japan.
\end{abstract}

\title{
Authors' contributions
}

TI and MK were mainly responsible for compiling the regional WIOT for Kyoto in 2000, with technical advice from MT. MT was responsible for data collection, performing calculations, and generating the quantitative results. MT interpreted the results and drew the conclusions. All authors read and approved the final manuscript.

\footnotetext{
Author details

1 School of Business and Commerce, Tokyo International University, 1-13-1 Matoba-Kita, Kawagoe-shi, Saitama 350-1197, Japan. ${ }^{2}$ Ministry of the Environment Government of Japan, Godochosha No. 5, Kasumigaseki 1-2-2, Chiyoda-ku, Tokyo 100-8975, Japan. ${ }^{3}$ Division of Natural Resource Economics, Graduate School of Agriculture, Kyoto University, Yoshida-honmachi, Sakyo-ku, Kyoto 606-8501, Japan.
}

\section{Acknowledgements}

We are grateful for useful advices in developing the methodology which were given by Dr. Shigemi Kagawa and Dr. Yasushi Kondo. We would like to thank Ms. Yumi Hatano who assisted with the compilation of the regional WIOT for Kyoto in 2000. We wish to thank Mr. Lorenz from Forte Inc. for proofreading this manuscript.

Competing interests

The authors declare that they have no competing interests.

Funding

This work was supported by a JSPS KAKENHI Grant (No. 19510049). MT developed the methodology.

Received: 17 August 2016 Accepted: 3 January 2017

Published online: 26 January 2017 
References

Archer B, Fletcher J (1996) The economic impact of tourism in the Seychelles. Ann Tour Res 23:32-47

Beylot A, Boitier B, Lancesseur N, Villeneuve J (2016) A consumption approach to wastes from economic activities. Waste Manag 49:505-515. doi:10.1016/j.wasman.2016.01.023

Cai J, Leung P, Mak J (2006) Tourism's forward and backward linkages. J Travel Res 45(1):36-52

CD-ROM Ministry of the Environment Secretariat, Waste/Recycling Measures Department (2002) 2004 project industrial waste generation/treatment conditions survey report, 2002 results

Cernat L, Gourdon J (2012) Paths to success: benchmarking cross-country sustainable tourism. Tour Manag 33:1044-1056

Dwyer L, Forsyth P, Madden J, Spurr R (2000) Economic impacts of inbound tourism under different assumptions regarding the macroeconomy. Curr Issues Tour 3:324-363

Dwyer L, Forsyth P, Spurr R (2004) Evaluating tourism's economic effects: new and old approaches. Tour Manag 25:307-317

Fernandez JIP, Rivero MS (2009) Measuring tourism sustainability: proposal for a composite. Tour Econ 15:277-296

Fletcher J (1989) Input-output analysis and tourism impact studies. Ann Tour Res 16:514-529

Frechtling DC, Horvath E (1999) Estimating the multiplier effects of tourism expenditures on a local economy through a regional input-output model. J Travel Res 37:324-332

Fry J, Lenzen M, Giurco D, Pauliuk S (2015) An Australian multi-regional waste supply-use framework. J Ind Ecol. doi:10.1111/jiec.12376

Hamada Y (2009) Destination image survey and application of regional I-O tables: the case of Yuda-Onsen, Yamaguchi City. Input Output Anal Innov I-O Tech 17(1-2):78-87 (in Japanese)

Hardy A, Beeton RJS, Pearson L (2002) Sustainable tourism: an overview of the concept and its position in relation to conceptualisations of tourism. J Sustain Tour 10(6):475-496

Hasegawa R, Kagawa S, Tsukui M (2015) Carbon footprint analysis through constructing a multi-region input-output table: a case study of Japan. J Econ Struct 4:5. doi:10.1186/s40008-015-0015-6

Ichikawa T, Kagatsume M, Tsukui M, Hatano Y (2011) The environmental effect of photovoltaic power generator for dwellings: analysis by Kyoto prefectural waste input-output table. In: Proceedings of the 6th meeting of the institute of life cycle assessment, Japan (Sendai Tohoku University Kawana Campus), pp 97-98

Isard W (1951) Interregional and regional input-output analysis: a model of a space economy. Rev Econ Stat 33:318-328 Johnson RL, Moore E (1993) Tourism impact estimation. Ann Tour Res 20:279-288

Kagawa S, Kondo Y (2007) Regional waste input-output analysis. In: Nakamura S (ed) Lifecycle input-output analysis. Waseda University, Tokyo, pp 105-140 (in Japanese)

Kagawa S, Nakamura S, Inamura H, Yamada M (2007) Measuring spatial repercussion effects of regional waste management. Resour Conserv Recy 51:141-174

Kansai Electric Power Co. Inc. (2011) KEPCO. http://www1.kepco.co.jp/fuel/siyounen.html. Accessed 1 Jun 2011

Ko TG (2005) Development of a tourism sustainability assessment procedure: a conceptual approach. Tour Manag 26(3):431-445

Kyoto City Industry and Tourism Bureau, Tourism Department, Tourism Planning Office (2002) 2001 Kyoto city annual tourism study report (2001). https://kanko.city.kyoto.lg.jp/chosa/image/kanko_chosa13.pdf. Accessed 1 Sept 2011

Kyoto Prefecture (2004) Year 2000 Kyoto prefecture input-output table. http://www.pref.kyoto.jp/tokei/cycle/sanren/ sanrentop.html. Accessed 10 Sept 2011

Kytzia S, Walz A, Wegmann M (2011) How can tourism use land more efficiently? A model-based approach to land-use efficiency for tourist destinations. Tour Manag 32(3):629-640

Lenzen M (2008) Sustainable island businesses: a case study of Norfolk Island. J Clean Prod 16(18):2018-2035

Liao M, Chen P, Ma H, Nakamura S (2015) Identification of the driving force of waste generation using a high-resolution waste input-output table. J Clean Prod 94(1):294-303

Matsuto T (2005) Analysis, planning and assessment of municipal solid waste. Gihodo Shuppan Co., Ltd, Tokyo (in Japanese)

Ministry of Internal Affairs and Communication (MIC) (2004) Year 2000 input-output comprehensive explanation compilation (in Japanese). http://www.soumu.go.jp/toukei_toukatsu/data/io/000index.htm. Accessed Oct 2010

Ministry of Land, Infrastructure, Transport and Tourism (MLITT) Policy Bureau, Travel Promotion Division (2004) 4th investigative study on the economic results of the travel and tourism industry, results of travel and tourism consumption trends and estimations of the economic results (travel and tourism consumption trends survey 2003)

Nakamura S (2010) Waste input-output table Japan 2000 (WIO2000) version 0.06. http://www.f.waseda.jp/nakashin/ wio_j.htm. Accessed 1 Oct 2010

Nakamura S, Kondo Y (2002a) Input-output Analysis of waste management. J Ind Ecol 6:39-64

Nakamura S, Kondo Y (2002b) Recycling, landfill consumption, and $\mathrm{CO}_{2}$ emission: analysis by waste input-output model. JSMCWM 4(1):2-11

Nakamura S, Kondo Y (2009) Waste input-output analysis: concepts and application to industrial ecology. Springer, Berlin

Nansai K, Moriguchi Y, Touno S (2008) Embodied energy and emission intensity data for japan using input-output tables. http://www.cger.nies.go.jp/publications/report/d031. Accessed 27 Dec 2010

New Energy and Industrial Technology Development Organization (NEDO) (2005) Report on research and development on the LCA for products and LCA for end-of-life stage, pp 408-426 (in Japanese)

Reynolds C, Piantadosi J, Boland J (2014) A waste supply-use analysis of australian waste flows. J Econ Struct 3(1):1-16. doi:10.1186/s40008-014-0005-0

Salemdeeb R, Al-Tabbaa A, Reynolds C (2016) The UK waste input-output table: linking waste generation to the UK economy. Waste Manag Res 34(10):1089-1094. doi:10.1177/0734242X16658545

Sasao T (2004) An estimation of the social costs of landfill siting using a choice experiment. Waste Manag 43:188-218

Sun Y (2014) A framework to account for the tourism carbon footprint at island destinations. Tour Manag 45:16-27

TMGA (Tokyo Metropolitan General Affairs) (2007) 2000 input-output tables of Tokyo, TMGA. http://www.toukei.metro. tokyo.jp/sanren/2000/sro0t1.HTM. Accessed 1 Apr 2007 
Tokyo Convention \& Visitors Bureau (2004) The number of tourists survey. http://www.gotokyo.org/jp/administration/ kankokyaku/index.html. Accessed 9 Sept 2013

Tsukui M, Nakamura K (2009) Modeling of waste transportation for the estimation of energy consumptions and $\mathrm{CO}_{2}$ emissions by multiple means of transportation. J Life Cycle Assess Japan 5(4):462-472

Tsukui M, Kagawa S, Kondo Y (2010) How consumption activities in a metropolitan area affect waste treatment and recycling activities in surrounding regions: an interregional waste input-output analysis of Tokyo. International Society for Industrial Ecology ISIE MFA ConAccount Miraikan

Tsukui M, Kagawa S, Kondo Y (2011a) Analyzing the environmental repercussion effects of metropolitan consumption activities: an interregional waste input-output approach. In: ISIE (International Society for Industrial Ecology) 2011 Conference of California, Berkeley, California, USA

Tsukui M, Ichikawa T, Kagawa S, Kondo Y, Kagatsume M (2011b) A regional WIO analysis of the effect of non-residents' consumption: a comparison between Tokyo and Kyoto. In: 19th international input-output conference, Crowne Plaza Old Town Alexandria, Virginia, USA

Tsukui M, Kagawa S, Kondo Y (2011c) A case study of an interregional WIO analysis of how consumers' final demands in Tokyo affect other region of Japan. In: Proceeding of the 6th meeting of the institute of life cycle assessment, Japan (Sendai Tohoku University Kawana Campus), pp 53-54

Tsukui M, Hasegawa R, Kagawas S, Kondo Y (2014) Repercussion of effects of final consumption on production and environmental loads: detailed multi-regional waste input-output approach in the 47 prefectures of Japan. In: 22nd international input-output conference, Lisbon, Portugal, 15 July 2014

Tsukui M, Kagawa S, Kondo Y (2015) Measuring the waste footprint of cities in Japan: an interregional waste input-output analysis. J Econ Struct. doi:10.1186/s40008-015-0027-2

UNWTO (2015) UNWTO tourism highlights, 2015 edition. http://www.e-unwto.org/doi/pdf/10.18111/9789284416899. Accessed 16 Mar 2016

\section{Submit your manuscript to a SpringerOpen ${ }^{\circ}$ journal and benefit from:}

- Convenient online submission

$\checkmark$ Rigorous peer review

- Immediate publication on acceptance

- Open access: articles freely available online

- High visibility within the field

- Retaining the copyright to your article

Submit your next manuscript at $\mathbf{s p r i n g e r o p e n . c o m ~}$ 